\title{
Enzyme Immobilization Onto Biochar Produced by the Hydrothermal Carbonization of Biomass
}

\author{
Mateja Primožič, ${ }^{1}$ Gordana Hojnik Podrepšek, ${ }^{1}$ Irena Pavlovičc, ${ }^{1}$ \\ Mojca Škerget, ${ }^{1}$ Željko Knez ${ }^{1,2}$ and Maja Leitgeb ${ }^{1,2, *}$ \\ ${ }^{1}$ University of Maribor, Faculty of Chemistry and Chemical Engineering, Laboratory for Separation Processes \\ and Product Design, Smetanova 17, 2000 Maribor, Slovenia \\ ${ }^{2}$ University of Maribor, Faculty of Medicine, Taborska ulica 8, 2000 Maribor, Slovenia \\ ${ }^{*}$ Corresponding author: E-mail: maja.leitgeb@um.si
}

Received: 02-01-2019

\begin{abstract}
For improving enzyme utilization in biotechnological processes, process costs have to be reduced, enzyme stability during industrial processes should be enhanced, and the recycle and reuse step should be favorable. The immobilization of enzymes is an important step for enhancing enzyme catalytic properties and operational stability. In order to reduce the costs of immobilization and consequently the cost of processes, a cheaper carrier (e.g. materials reclaimed as by-products) should be used. To achieve this, cellulase from Trichoderma sp. was immobilized on biochar obtained by low temperature hydrothermal carbonization (LTHTC) in two ways: by adsorption and by covalent binding via a crosslinking agent. The effect of immobilization time, enzyme concentration, type and concentration of the crosslinking agent and the types of carrier - biochar (LTHTC of waste from olive oil production (LTHTC of OL waste) or LTHTC of cellulose) on the immobilization efficiency and the residual activity of biocatalyst was studied. Higher immobilization efficiency and residual enzyme activity was achieved when the enzyme was covalently bound to biochar obtained by LTHTC of cellulose.
\end{abstract}

Keywords: Hydrothermal carbonization; biochar; enzyme; immobilization; enzyme activity.

\section{Introduction}

Energy shortages, the environmental crisis and rising consumer demands for better materials have led to new research into lightweight, inexpensive, environmentally friendly and non-toxic new functional materials. Biomass is a source of raw carbon for the synthesis of valuable carbon materials, since it is available in high quality (for example, as a pure sucrose) and in large quantities as environmentally friendly renewable sources. Among various techniques, the hydrothermal carbonization (HTC) of biomass is a promising method for the synthesis of new materials based on carbon (commonly named as biochar or hydrochar) and other carbonaceous materials (e.g. carriers for enzyme immobilization ${ }^{9}$ ) with a wide range of possible applications in the field of precursor preparation of activated carbon ${ }^{1,2,3}$ in wastewater pollution remediation, ${ }^{4,5}$ soil remediation applications, ${ }^{5}$ solid fuels, ${ }^{6,7}$ gas sensors ${ }^{8}$ and other carbonaceous materials (e.g. carrier for enzyme immobilization ${ }^{9}$ ). The concept of HTC was initially intro- duced by Friedrich Bergius in $1913 .{ }^{10}$ Low temperature hydrothermal carbonization (LTHTC) of biomass is a process based on the reaction of biomass with sub-critical water at temperatures up to $250{ }^{\circ} \mathrm{C}$ to form nano- and micro-porous carbon structures with reactive surfaces consisting of hydroxyl and carboxyl groups that have potential for binding different compounds. For converting biomass into biochar, LTHTC is preferable, because the process itself is closer to the natural process of biomass transformation into charcoal. Advantages of the HTC process are very low toxicological impact of material and processes, use of renewable materials without prior dewatering (water acts as a reaction media), simple apparatus and techniques for the synthesis, and high energy and highly efficient atom economy. ${ }^{11-13}$ Methods of saccharide treatment (glucose, sucrose, and starch) under hydrothermal conditions (in an aqueous medium at temperatures $>170$ ${ }^{\circ} \mathrm{C}$ ) leads to the formation of solid carbonaceous residue (biochar) with a structure of micrometer sized spheres (0.4 to $6.0 \mathrm{~mm}$ ). The diameter of these spheres can be altered 
by changing the synthesis conditions. ${ }^{11,14,15}$ Thus, synthesized biochar has two important properties that make it suitable for use in the field of catalysis, as a carrier for drugs with controlled release, ${ }^{16}$ or for immobilization of enzymes (purified ${ }^{17,18,19}$ or within microbial cells ${ }^{20,21}$ ). First, it contains a high concentration of oxygen groups on the surface, which means that it can be easily connected to other substances with complementary features and it is suitable for the manufacture of functional nanocomposites. Secondly, the diameter can be smaller than $500 \mathrm{~nm}$, which is compatible with in vivo applications. All these properties are also suitable for biochar usage as a carrier for biocatalysts. A good carrier should be insoluble, non-toxic, easily accessible, inexpensive, stable and suitable for regeneration. For example, carriers used for adsorption or binding on the surface should have a high porosity to ensure that the contact area is as large as possible. ${ }^{22}$

The production of biochar from waste biomass is sustainable and zero waste production with the goal of eliminating greenhouse gas emissions and reducing carbon footprint. Biochar is therefore, from both an environmental and an economical perspecive, a very suitable carrier for enzyme immobilization, since it is biodegradable, biocompatible, and inexpensive to produce from food industry waste. Biochar thus has primarily an economic and environmental advantages over other carriers for the immobilization of enzymes.

The application of biochar as a carrier for enzyme immobilization has not been widely studied. Noritomi et al. ${ }^{23}$ found that bamboo charcoal powder (BCP), which was prepared from bamboo wastes by pyrolysis at low temperatures, is very useful as a carrier for the thermal stabilization of hen egg white lysozyme (HEWL) and a-chymotrypsin (CT), which were effectively adsorbed onto BCP. The thermal stability of BCP-adsorbed HEWL was strongly dependent upon adsorption conditions, such as solution $\mathrm{pH}$, ionic strength, and temperature. Unmodified charcoal support was used for the immobilization of amyloglucosidase for starch hydrolysis. Without any additional treatment, immobilized amyloglucosidase retained over $90 \%$ of its free enzyme catalytic activity. ${ }^{24}$ Additionally, activated carbon was used as a carrier for pancreatin using adsorption immobilization techniques with a total immobilization yield that resulted in the creation of biocatalytic systems with good catalytic properties. ${ }^{25}$

In recent years, enzyme immobilization has been presented as a powerful tool for the improvement of enzyme properties such as stability and reusability. However, the type of support material used plays a crucial role in the immobilization process due to the strong effect of these materials on the properties of the produced catalytic system.

Better stability, longer enzyme life time, easier separation of the enzyme from the reaction mixture, reusability of the enzyme and reduced contamination of the product during the process are decisive factors which encourage the use of immobilized against non-immobilized enzymes in biocatalysis. ${ }^{26}$

Enzyme immobilization by adsorption on an active material is a simple process, wherein the enzyme is reversibly adsorbed on the insoluble carrier, easily achieved by contact of the carrier with an aqueous solution of the enzyme. It is well known that any carrier can be applied for enzyme adsorption, but not every enzyme can be immobilized on all carriers. For successful adsorption of the enzyme onto the carrier, certain conditions must be fulfilled, among which an enzyme-carrier affinity is most important. The presence of specific active groups on the carrier which enable the generation of the enzyme-carrier interactions assures this affinity. ${ }^{27}$ This method includes particular weak interactions such as electrostatic, van der Waals forces, ionic and hydrogen bonds. For this reason, covalent immobilization of the enzyme on an insoluble substrate is more prevalent.

An immobilized enzyme can be reused several times, which results in a simple process and lower production costs. Immobilization may also be a tool to improve enzyme properties, including stability, activity, selectivity or specificity. 28,29

Microbial cellulases have shown their potential application in various industries, including pulp and paper, textile, laundry, biomass treatment, biofuel production, the food and feed industries, brewing, and agriculture. Cellulase from Trichoderma $s p$. has been successfully immobilized on different magnetic nanoparticles, ${ }^{30}$ chitosan microparticles, ${ }^{31}$ surface modified coffee, ${ }^{32}$ silica particles grafted with polyacrylic acid polymer brushes, ${ }^{33}$ and as a crosslinked cellulase aggregates, ${ }^{34}$ but until now, no immobilization on biochar has been reported. Therefore, cellulase from Trichoderma sp. (Cellusoft conc. L) was immobilized on biochar in two ways: by adsorption and by covalent binding via crosslinking agent. The effect of immobilization time, enzyme concentration, type and concentration of the crosslinking agent and the types of carrier - biochar (LTHTC of waste from olive oil production (LTHTC of OL waste) or LTHTC of cellulose) on immobilization efficiency and the residual activity of biocatalyst was studied.

\section{Experimental}

\section{1. LTHTC of Waste from the Olive Oil Production and Cellulose}

Carbonized material used in the experiments was prepared by the LTHTC of semi-solid olive mill waste (about 75\% (w/w) water) and cellulose. Hydrothermal carbonization was carried out in a $75 \mathrm{~mL}$ Parr Instruments autoclave (Moline, IL, USA), designed for a maximal operating temperature and pressure of $550{ }^{\circ} \mathrm{C}$ and 586 bar, respectively. The autoclave was filled with a suspension of wet waste from the production of olives or cellulose and 
deionised water. The reaction was carried out for 4 hours at $220{ }^{\circ} \mathrm{C}$ and $3 \mathrm{MPa}$. After reaction, the carbonized residue was separated from the aqueous phase by filtration through filter paper (pore size $10 \mathrm{~mm}$ ), washed with deionized water and methanol and dried overnight in an oven at $105^{\circ} \mathrm{C}$.

\section{2. Characterization of the Biochar}

The pore size and BET surface areas of biochar were determined by nitrogen physisorption using a TriStar 3000 surface area and porosimetry analyser from Micromeritics.

Average particle size was measured with a granulometer (Fritsch analysette 22, Germany) operating on the principle of laser diffraction spectroscopy.

\section{3. Adsorption of Biocatalysts on Biochar}

Various cellulase concentrations (liquid form - Cellusoft conc. L, NovoNordisk A/S) were adsorbed on $5 \mathrm{mg}$ of selected biochar. Adsorption took place for 24 hours with continuous stirring (300 rpm) on an orbital shaker (Innova ${ }^{\circledR} 2000$, New Brunswick) in the presence of phosphate buffer (PBS) pH 5 or 7 at ambient temperature and atm. pressure. After adsorption, the biochar was separated from the rest of the solution by centrifugation (Centrifuge $5804 \mathrm{R}$, Eppendorf), washed with deionized water and dried in an exicator. The experiments were repeated three times.

\section{4. Covalent Immobilization of Enzyme Onto Biochar}

Cellulase in liquid form (Cellusoft conc. L, NovoNordisk A/S) was covalently immobilized on $5 \mathrm{mg}$ of selected biochar. First, the crosslinking agent (homobifunctional agent - gluteraldehide (GA) or pentaethylenehexamine (PEHA)) was bound on the biochar. Activation lasted 1 hour at ambient temperature and atm. pressure during continuous shaking on an orbital shaker $(300 \mathrm{rpm})$. The activated carrier was washed with PBS $(3 \times 20 \mathrm{~mL})$. The immobilization of cellulase on activated carrier was carried out at ambient temperature and atm. pressure by shaking on an orbital shaker for different time $(2,7$ or 24 hours) and in the presence of the PBS with selected $\mathrm{pH}$. After immobilization, the immobilized carrier was washed with PBS until no proteins in the supernatant were detected. The experiments were repeated three times.

\section{5. Determination of the Protein Concentration}

The total protein concentration was assayed using the Bradford method at a wavelength of $595 \mathrm{~nm} .{ }^{35}$ The method for determination of protein concentration is based on the binding of Coomassie Brilliant Blue dye via electrostatic interactions in the protein molecule. Measurements were carried out using UV-Vis spectrophotometer (Varian Cary Probe 50, Agilent technologies) at a wavelength of $595 \mathrm{~nm}$. The protein concentration in the supernatant was determined on the basis of the calibration curve. The resulting protein concentrations represent the concentration of the proteins, which are not adsorbed or bound to the carrier. Thus, the efficiency of adsorption or immobilization could be recalculated.

\section{6. Determination of Cellulase Activity}

Cellulase activity was determined by a specific activity assay. ${ }^{36} 4 \mathrm{~mL}$ of a Sigmacell (crystalline cellulose - Type 20, $20 \mu \mathrm{m}$, from Sigma Aldrich S 3504) solution (5\% w/v) was added to the immobilized or adsorbed enzyme with different concentrations $(1.06 \mathrm{mg} / \mathrm{ml}, 2.31 \mathrm{mg} / \mathrm{ml}$ or 4.21 $\mathrm{mg} / \mathrm{ml}$ ) $4 \mathrm{~mL}$ of a Sigmacell (crystalline cellulose - Type 20, $20 \mu \mathrm{m}$, from Sigma Aldrich S 3504) solution (5\% w/v) was added and the mixture was shaken on an orbital shaker for 2 hours at a temperature of $37^{\circ} \mathrm{C}$. Next, the initial rate of the reaction with a UV-Vis spectrophotometer at $340 \mathrm{~nm}$ was defined. The residual activity of an immobilized enzyme according to the initial value of the free cellulase was determined based on these measurements.

\section{Results and Discussion}

\section{1. Characteristics of Obtained Biochars}

Biochars, produced from different materials by LTHTC (OL waste or cellulose), were used as carriers for immobilization of cellulase. Characteristics of biochars are presented in Table 1.

Table 1. Surface area, pore size and average particle size of biochar produced by LTHTC of OL waste and biochar produced by LTHTC of cellulose.

\begin{tabular}{lrr}
\hline & $\begin{array}{c}\text { Biochar } \\
\text { produced } \\
\text { by LTHTC } \\
\text { of OL waste }\end{array}$ & $\begin{array}{c}\text { Biochar } \\
\text { produced } \\
\text { by LTHTC } \\
\text { of cellulose }\end{array}$ \\
\hline Surface Area $\left(\mathrm{m}^{2} / \mathrm{g}\right)$ & $6.40 \pm 0.11$ & $41.70 \pm 0.54$ \\
Pore Size $(\mathrm{nm})$ & $35.90 \pm 0.63$ & $23.71 \pm 0.37$ \\
Average Particle Size $(\mathrm{nm})$ & $938.02 \pm 0.97$ & $143.88 \pm 0.72$ \\
\hline
\end{tabular}

Although both biochars were produced under the same conditions, significant differences in their surface characteristics appeared. Biochar produced by LTHTC of cellulose had a larger surface area $\left(41.70 \pm 0.54 \mathrm{~m}^{2} / \mathrm{g}\right)$, but bigger pore size was defined at biochar produced by LTHTC of OL waste $(35.90 \pm 0.63 \mathrm{~nm})$. The average particle size of biochars produced by LTHTC of OL waste was $938.02 \pm 0.97 \mathrm{~nm}$, and of cellulose, $143.88 \pm 0.72 \mathrm{~nm}$. The high surface area and small particle size of biochars pro- 
duced by LTHTC present suitable properties as potential carriers for enzyme immobilization.

\section{2. Adsorption of Cellulase onto Biochar}

The liquid form of cellulase (Cellusoft conc. L) was adsorbed onto the biochar produced by LTHTC of OL waste and LTHTC of cellulose. Adsorption of enzymes onto insoluble supports is a simple and widely used method capable of providing high enzyme loading (about one gram per gram of matrix). The driving force causing this binding is usually a combination of hydrophobic effects and the formation of several salt links per enzyme molecule. Therefore, the binding of an enzyme to the carrier is enabled mainly by hydrogen bonds, multiple salt linkages, and van der Waal's forces. Different concentrations of enzyme in PBS with $\mathrm{pH} 7$ were added to $5 \mathrm{mg}$ of selected biochar and the immobilization procedure described under section 2.3 Adsorption of biocatalysts on biochar was achieved. The concentration of added enzyme was optimized and its influence on the immobilization efficiency and residual enzyme activity was studied. Immobilization efficiency increased proportionally with the increase in the concentration of added enzyme, regardless of the type of biochar (Fig. 1). Both types of biochar contain many specific active groups on the carrier, which enable the generation of enzyme-carrier interactions, and consequently higher concentration of enzyme was adsorbed on both carriers. The highest immobilization efficiency was achieved when the concentration of added enzyme was $2.31 \mathrm{mg} / \mathrm{ml}$. Immobilization efficiency remains unchanged with further increase in the enzyme concentration. Comparison between the types of biochar (LTHTC of OL waste or LTHTC of cellulose) shows that the biochar produced from OL waste is better adsorbent since the higher effi-

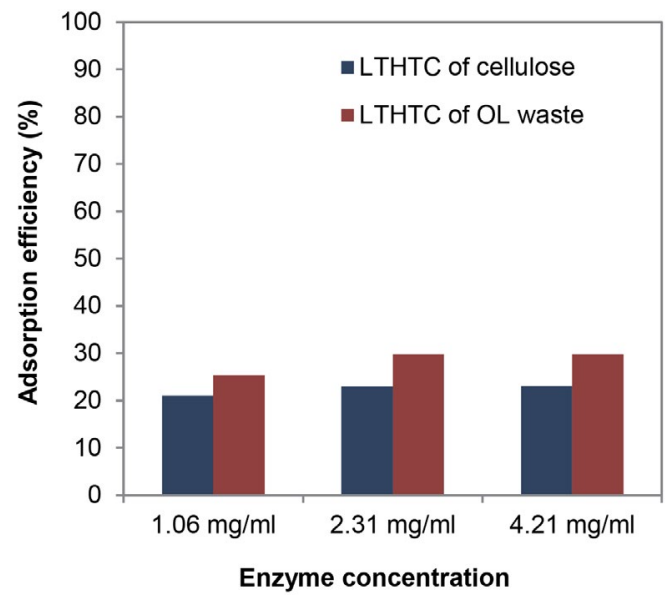

Figure 1. Influence of enzyme concentration on adsorption efficiency of biochar from two different sources (LTHTC of OL waste or LTHTC of cellulose). Reaction conditions: $5 \mathrm{mg}$ of chosen biochar, PBS with $\mathrm{pH} 7,24-\mathrm{h}$ adsorption with continuous stirring at 300 $\mathrm{rpm}$, at ambient temperature and at atm. pressure. Standard deviation for all measurements was less than $\pm 3 \%$. ciency of enzyme adsorption was achieved. The reason for higher obtained efficiency using biochar produced from OL waste as a carrier could be in bigger pore size of carrier in comparison to the biochar produced from cellulose. Due to bigger pores size of OL waste, better accessibility for the enzyme and also higher active surface area for the immobilization of the enzyme onto OL waste carrier was provided. Therefore, the enzyme adsorption was more successful because of better matching of the enzyme into the pores of the biochar, Consequently, the active side of the enzyme could be better oriented toward the substrate.

\section{2. Covalent Immobilization of Cellulase onto Biochar}

Enzyme immobilization on carriers via a spacer arm presents a good way to avoid steric hindrance and to increase enzyme activity. Using this type of immobilization, a spacer arm is formed between enzyme and carriers by means of a bifunctional reagent such as GA, PEHA, or isocyanate. With the introduction of a flexible spacer arm onto the supports, the enzyme can be allowed to stretch flexibly and catch the substrate more easily. ${ }^{37}$

\section{3. 1. The Impact of Crosslinking Agents on the Immobilization Efficiency and Activity of a Biocatalyst}

In the process of covalent immobilization of the enzyme on a solid support, active sites on the carrier are required to form a covalent bond between the carrier and the enzyme. Therefore, the carrier has to be activated by a crosslinker. As a crosslinker, various concentrations of GA $(1.5(\mathrm{v} / \mathrm{v}) \%$ and $3(\mathrm{v} / \mathrm{v}) \%)$ and PEHA $(0.02 \mathrm{M})$ were used. After one-hour activation of the carrier, 24-h immobilization of the enzyme on the carrier was followed at ambient temperature and atm. pressure. Higher immobilization efficiency was achieved when 3 (v/v)\% GA was used (Fig. 2), but higher residual activity of the enzyme was detected using PEHA as a crosslinker. Too high concentration of GA could lower enzyme activity. The reaction mechanism of GA with proteins is not limited to just one mechanism, because the main reactive species of GA are found in equilibrium between their monomeric and polymeric conformations. Moreover, every structure can react in a different way with the protein. Under acidic and neutral conditions, aldehyde groups from GA can react with proteins by formation of Schiff bases, while under basic conditions it has been proposed that GA quickly suffers intramolecular aldolic condensations, producing a polymeric form of an $\alpha, \beta$-unsaturated aldehyde, which may react with amino groups from proteins through two mechanisms, firstly, by formation of Schiff bases between internal aldehyde groups from the polymeric form of GA and primary amino groups from the protein. The second mechanism involves a Michael addition to the double C-C linkage, re- 
sulting in a less stable product. ${ }^{38}$ Too much cross-linker can result in a loss of the minimum flexibility needed for enzyme activity, ${ }^{39}$ and low concentrations of GA are not able to form sufficient crosslinkages to effect precipitation of the enzyme. Partial enzyme inactivation due to chemical modification is often unavoidable. ${ }^{40}$ Chui and $\mathrm{Wan}^{41}$ indicated that enzymatic activity was inversely proportional to the concentration of added GA, because extensive crosslinking may result in a distortion of the enzyme structure (i.e., the active site conformation). As can be seen from Fig. 2, bioachar produced from cellulose shows higher residual activity of immobilized biocatalyst than biochar produced by LTHTC of OL waste. Moreover, cellulose has good potential for varied derivatization due to the presence of three hydroxyl groups in every monomeric unit. ${ }^{42}$ The addition of PEHA increases the number of free amino groups $\left(-\mathrm{NH}_{2}\right)$ on the outer surface of the enzyme, thus facilitating the crosslinking. Additionally, activation of biochar via PEHA provides active primary amino groups via a long spacer arm. A 19-atom spacer arm of PEHA contains hydroxyl and amino groups onto which immobilization of the cellulase can be performed. The presence of PEHA ensures that steric limitations during the protein immobilization are kept to a minimum. A second benefit arising from the use of a PEHA is that interactions between the protein and the surface of the carrier can be minimized because the protein is kept away from the particle surface by the long space arm. ${ }^{43}$

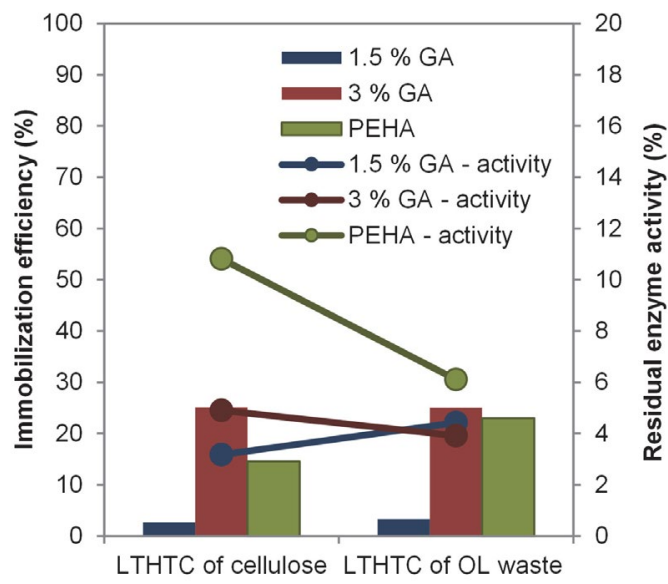

Figure 2. Influence of crosslinker on immobilization efficiency and residual enzyme activity. Reaction conditions: $5 \mathrm{mg}$ of chosen biochar, enzyme concentration of $2.3 \mathrm{mg} / \mathrm{mL}$, PBS with $\mathrm{pH}$ 7, 7-h immobilization of enzyme with continuous stirring at $300 \mathrm{rpm}$, at ambient temperature and at atm. pressure. Standard deviation for all measurements was less than $\pm 3 \%$.

As can be seen from Fig. 2, despite the lower immobilization efficiency for biochar produced by LTHTC of cellulose, higher residual enzyme activity when using PEHA as a crosslinker was detected. This could be due to the orientation of the active sides of the immobilized enzyme. If a higher amount of enzyme is attached to the carrier, the orienta- tion of enzyme active sides could be unsuitable for successful contact between the active site of the enzyme and the substrate. Besides, the immobilization efficiency and enzyme activity are also dependent on the carrier properties (surface area, pore size, and particle size) and subsequent internal and external mass transfer phenomena. ${ }^{44,45}$

\section{3. 2. The Influence of $\mathbf{p H}$ on the Immobilization Efficiency and Activity of the Biocatalyst}

Most enzymes have an optimal $\mathrm{pH}$ at which their activity is maximal. It is well known that the $\mathrm{pH}$ of the immobilization medium has a significant effect on immobilization efficiency and enzyme activity. If the $\mathrm{pH}$ value of the medium in which the reaction is carried out is changed, a change in the three-dimensional structure of the protein and a subsequent loss of protein activity may occur. $\mathrm{pH}$ may affect the activity of the enzyme, and therefore the effect of $\mathrm{pH}$ on immobilization efficiency and immobilized cellulase activity was studied. For the study, PBS pH 7 and acetate buffer $\mathrm{pH} 5$ were used. From Fig. 3, it is evident that higher residual activity of the immobilized enzyme was obtained when buffer PBS with $\mathrm{pH} 7$ was used, regardless of the selected biochar. Noritomi at al. ${ }^{46}$ also reported that maximum adsorptions of $\alpha$-chymotrypsin on adzuki bean charcoal and bagasse charcoal were observed at near neutral $\mathrm{pH}$. The loss in enzymatic activity at too high and too low $\mathrm{pH}$ values may be attributed to alterations in enzyme conformation resulting in decrease in immobilization efficiency.

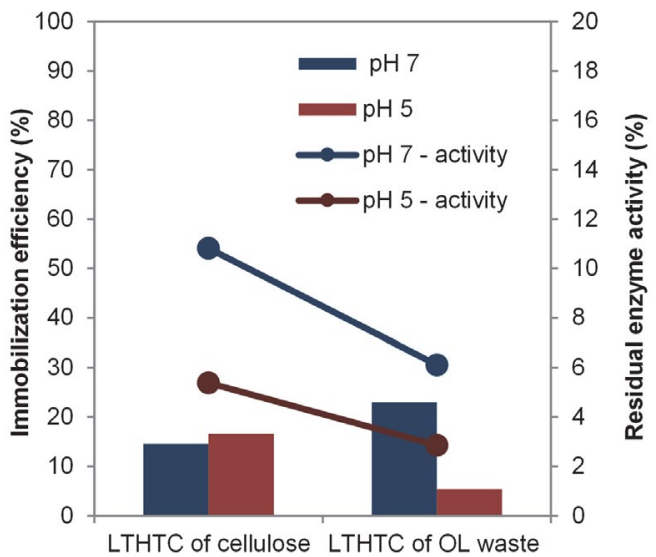

Figure 3. Influence of $\mathrm{pH}$ on immobilization efficiency and residual enzyme activity. Reaction conditions: $5 \mathrm{mg}$ of chosen biochar, enzyme concentration of $2.3 \mathrm{mg} / \mathrm{mL}$, crosslinker PEHA, 7-h immobilization of enzyme with continuous stirring at $300 \mathrm{rpm}$, at ambient temperature and at atm. pressure. Standard deviation for all measurements was less than $\pm 3 \%$.

\section{3. 3. Influence of Immobilization Time on the Immobilization Efficiency and Activity of the Biocatalysts}

The effect of coupling time on immobilization was investigated in terms of residual activity of cellulase and im- 
mobilization efficiency. The liquid form of cellulase (Cellusoft conc. L) was immobilized on two different carriers (LTHTC of OL waste or LTHTC of cellulose), and the time of immobilization (2, 7 or $24 \mathrm{~h}$ ) was optimized (Fig. 4).

With an increase in the immobilization time, immobilization efficiency and residual enzyme activity increased. The optimal immobilization time was found to be 7 hours, since with further increases in the immobilization time no significant differences in immobilization efficiency and residual enzyme activity were detected in spite of the origin of the biochar.

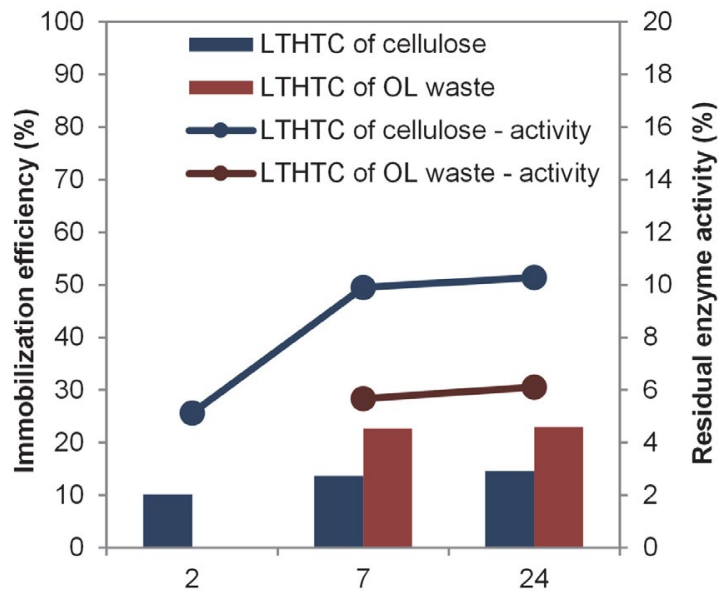

Figure 4. Influence of immobilization time on immobilization efficiency and residual enzyme activity. Reaction conditions: $5 \mathrm{mg}$ of chosen biochar, enzyme concentration of $2.3 \mathrm{mg} / \mathrm{mL}$, crosslinker PEHA, PBS with $\mathrm{pH} 7$, ambient temperature and atm. pressure. Standard deviation for all measurements was less than $\pm 3 \%$.

\section{3. 4 The Influence of Agitation Speed on Immobilization Efficiency and Activity of Biocatalysts}

During the immobilization process, the enzyme is in contact with the carrier. Shaking allows more intensive contact between the enzyme and the carrier and consequently the immobilization efficiency can be improved. The effect of agitation speed on immobilization efficiency and residual activity of immobilized cellulase was studied. The enzyme and carrier were intensively shaken on a shaker at $300 \mathrm{rpm}$ and $500 \mathrm{rpm}$ for 7 hours. Higher immobilization efficiency and residual enzyme activity were achieved when the carrier and the enzyme were shaken at lower agitation speed. Higher agitation speeds obviously shortened the time of contact between the enzyme and the carrier; therefore, immobilization efficiency and residual enzyme activity decreased (Fig. 5).

\section{Conclusions}

LTHTC of semi-solid waste from olive oil and cellulose production was performed to produce biochar. A

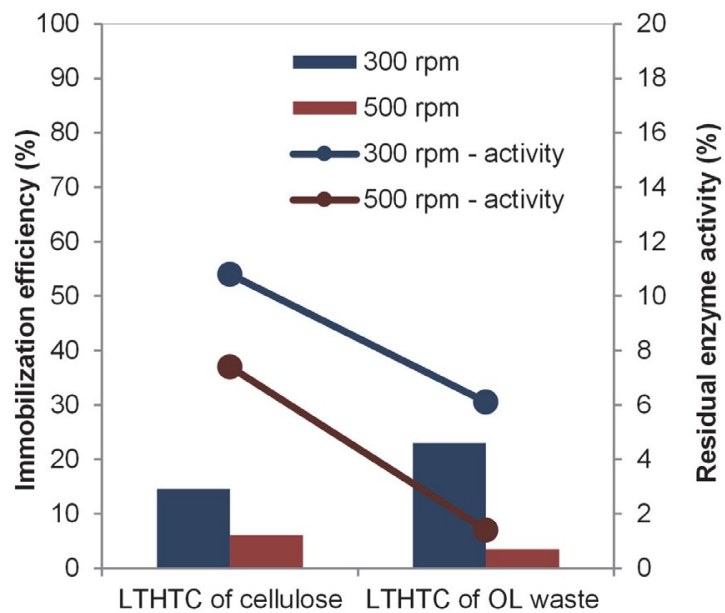

Figure 5. Influence of agitation speed on immobilization efficiency and residual enzyme activity. Reaction conditions: $5 \mathrm{mg}$ of chosen biochar, enzyme concentration of $2.3 \mathrm{mg} / \mathrm{mL}$, crosslinker PEHA, PBS with pH 7, 7-h immobilization of enzyme with continuous stirring at ambient temperature and at atm. pressure. Standard deviation for all measurements was less than $\pm 3 \%$.

higher surface area was detected when the biochar was produced by LTHTC of cellulose, but bigger pore size was detected in biochar produced by LTHTC of OL waste. Biochars produced by LTHTC were successfully used as carriers for enzyme immobilization.

Studies have shown that biochars produced by LTHTC are suitable carriers for enzyme immobilization. Various parameters that affect the immobilization efficiency and residual activity of immobilized cellulase were tested. Biochar from cellulose proved to be a more suitable carrier for cellulase immobilization, because immobilized cellulase on those biochar retains higher residual activity as in the case when the cellulase was immobilized on the biochar produced by LTHTC of OL waste. Higher immobilization efficiency and enzyme activity was achieved when the enzyme was covalently bound onto biochar obtained by LTHTC of cellulose. Moreover, immobilization of an enzyme on these carriers results in a closed-loop productive system, which is the basis for a circular economy. Joining immobilization of enzymes on one hand with production of biochar on the other leads not only to a reduction of costs for biocatalysts, but also to more sustainable production.

\section{Acknowledgments}

The authors acknowledge the financial support of the Slovenian Research Agency (research core funding No. P2-0046 - "Separation Processes and Product Design").

\section{References}

1. T. Wanga, Y. Zhaia, Y. Zhu, C. Lia, G. Zenga, Renew. Sust. Energ. Rev. 2018, 90, 223-247. 
2. H. S. Kambo, A. R. Dutta, Renew. Sust. Energ. Rev. 2015, 45, 359-378. DOI:10.1016/j.rser.2015.01.050

3. A. Jain, R. Balasubramanian, M. P. Srinivasan, Chem. Eng. J. 2016, 283, 789-805. DOI:10.1016/j.cej.2015.08.014

4. K. Vikrant, K. H. Kim, Y. S. Ok, D. C. W. Tsang, Y. F. Tsang, B. S. Giri, R. S. Singh, Sci. Total. Environ. 2018, 616, 1242-1260. DOI:10.1016/j.scitotenv.2017.10.193

5. M. Ahmad, A. U. Rajapaksha, J. E. Lim, M. Zhang, N. Bolan, D. Mohan, M. Vithanage, S. S. Lee, Y. S. Ok, Chemosphere. 2014, 99, 19-33. DOI:10.1016/j.chemosphere.2013.10.071

6. A Sharma, V. Pareek, D. K. Zhang, Renew. Sust. Energ. Rev. 2015, 50, 1081-1096. DOI:10.1016/j.rser.2015.04.193

7. Z. G. Liu, G. H. Han, Fuel. 2015, 158, 159-165. DOI:10.1016/j.fuel.2015.05.032

8. D. Ziegler, P. Palmero, M. Giorcelli, A. Tagliaferro, J.-M. Tulliani, Chemosensors. 2017, 5, 35.

DOI:10.3390/chemosensors5040035

9. H. Noritomi (December 31, 2018). Application of Biochar to Enzyme Carrier for Stress Tolerance of Enzymes, IntechOpen, https://www.intechopen.com/online-first/application-of-biochar-to-enzyme-carrier-for-stress-tolerance-of-enzymes.

DOI:10.5772/intechopen.82094

10. F. Bergius, J. Soc. Chem. Ind. 1913, 32, 462-467. DOI:10.1002/jctb.5000320904

11. B. Bo Hu, K. Wang, L. Wu, S. H. Yu, M. Antonietti, M. M. Titirici, Advan. Mater. 2010, 22, 813-828.

DOI:10.1002/adma.200902812

12. B. M. Ghanim, D. S. Pandey, W. Kwapinski, J. J. Leahy, Bioresour. Technol. 2016, 216, 373-380.

DOI:10.1016/j.biortech.2016.05.087

13. M. Volpe, L. Fiori, J. Anal. Appl. Pyrolysis. 2017, 124, 63-72. DOI:10.1016/j.jaap.2017.02.022

14. M. Sevilla, A. B. Fuertes, Chem. Eur. J. 2009, 5, 4195-4203. DOI:10.1002/chem.200802097

15. S. Malghani, G. Gleixner, S. E. Trumbore, Soil Biol. Biochem. 2013, 62, 137-146. DOI:10.1016/j.soilbio.2013.03.013

16. N. A. Salem, S. M. Yakoot, Int. J. Pharmacol. 2016, 12, 729736. DOI:10.3923/ijp.2016.729.736

17. N. Li, Q. Xia, M. Niu, Q. Ping, H. Xiao, Sci. Rep. 2018, 8, Article number: 13947.

18. J. A. Ghafil, World J. Exp. Biosci. 2013, 1, 33-36. DOI:10.1016/S0262-1762(13)70213-X

19. M. A. Abu-Tahon, H. H. Arafat, G. S. Isaac, Int. J. Adv. Biotechnol. Res. 2018, 9, 341-356.

20. L. Lu, A. A. Li, X.Q. Ji, C. P. Yang, S. Y. He, RSC Adv. 2018, 8, 23426-23432. DOI:10.1039/C8RA03529F

21. N. J. Pino, L. M. Munera, G. A. Penuela, Soil Sediment Contam. 2016, 25, 419-430.

DOI:10.1080/15320383.2016.1148010

22. S. C. S. Martins, C. M. Martins, L. M. C.Fiuza, Afr. J. Biotechnol. 2013, 2, 4412-4418.

23. H. Noritomi, S. Kurihara, N. Endo, S. Kato, K. Uchiyama, Int. J. GEOMATE 2016, 11, 2123-2128.

24. A. S. Rani, M. L. M. Das, S. Satyanarayana, J. Mol. Catal. B Enzym. 2000, 10, 471-476.

DOI:10.1016/S1381-1177(99)00116-2
25. V. D. M. Silva, L. M. De Marco, F. M. Delvivo, J.V. Coelho, M. P. C. Silvestre, Acta Sci. Health Sci. 2005, 27, 163-169.

26. S. Datta, L. R. Christena, Y. R. Sriramulu Rajaram, 3 Biotech 2013, 3, 1-9. DOI:10.1007/s13205-012-0071-7

27. T. Jesionowski, J. Zdarta B. Krajewska, Adsorption 2014, 20, 801-821. DOI:10.1007/s10450-014-9623-y

28. C. Mateo, J. M. Palomo, G. Fernandez-Lorente, J.M. Guisan, R. Fernandez-Lafuente, Enzyme Microb. Technol. 2007, 40, 1451-1463. DOI:10.1016/j.enzmictec.2007.01.018

29. S. A. Ansari, Q. Husain, Biotechnol. Adv. 2012, 30, 512-523. DOI:10.1016/j.biotechadv.2011.09.005

30. K. Khoshnevisan, F. Vakhshiteh, M. Barkhi, H. Baharifar, E. Poor-Akbar, N. Zari, H. Stamatis, A.K. Bordbar, Mol. Catal. 2017, 442, 66-73. DOI:10.1016/j.mcat.2017.09.006

31. A. Hamzah, L. L. Sitompul, I. N. F. Putri, Soeprijanto, A. Widjaja, Indones. J. Chem. 2019, 19, 495-502.

DOI:10.22146/ijc.39714

32. A. Buntic, M. Pavlovic, D. Antonovic, V. Pavlovic, D. Vrucinic, S. Siler-Marinkovic, S. Dimitrijevic-Brankovic, Int. J. Biol. Macromol. 2018, 107, 1856-1863.

DOI:10.1016/j.ijbiomac.2017.10.060

33. A. Samaratunga, O. Kudina, N. Nahar, A. Zakharchenko, S. Minko, A. Voronov, S. W. Pryor, Appl. Biochem. Biotechnol. 2015, 175, 2872-2882. DOI:10.1007/s12010-014-1463-4

34. L. Sutarlie, K. L.Yang, J. Colloid. Interface. Sci. 2013, 1, 76-81. DOI:10.1016/j.jcis.2013.09.005

35. M. M. Bradford, Anal. Biochem. 1976, 72, 248-254. DOI:10.1006/abio.1976.9999

36. M. Leitgeb, M. Čolnik, M. Primožič, P. Zalar, N. Gunde Cimerman, Ž. Knez, J. Supercrit. Fluid. 2013, 78, 143-148. DOI:10.1016/j.supflu.2013.03.029

37. D.-H. Zhang, L.-X. Yuwen, L.-J. Peng, J. Chem. 2013, 2013 (Article ID 946248), 1-7. DOI:10.1155/2013/946248

38. O. Barbosa, C. Ortiz, A. Berenguer-Murcia, R. Torres, R.C. Rodrigues, R. Fernandez-Lafuente, RSC Adv. 2014, 4, 1583 1600. DOI:10.1039/C3RA45991H

39. J. D. Cui, L. L. Li, H. J. Bian, PLoS ONE 2013, 8, e80581. DOI:10.1371/journal.pone.0080581

40. I. Migneault, C. Dartiguenave, M. J. Bertrand, K. C. Waldron, BioTechniques 2004, 37, 790-802.

DOI:10.2144/04375RV01

41. K. W. Chui, S.L. Wan, J. Microencapsul. 1997, 14, 51-61. DOI:10.3109/02652049709056467

42. M. D. Trevan, (ed.): An Introduction and Applications in Biotechnology, J. Wiley \& Sons, Chichester, 1980.

43. J. Aniulyte, J. Bryjak, J. Liesiene, Proc. Estonian Acad. Sci. Chem. 2006, 55, 61-69.

44. K. Buchholz, V. Kasche, U. T. Bornscheuer, in: Biocatalysts and Enzyme Technology, $2^{\text {nd }}$ Edition, Wiley-VCH, Weinheim, Germany, 2012.

45. P.M. Doran, in: Bioprocess Engineering Principles, $2^{\text {nd }}$ Edition, Academic Press, Elsevier, Waltham, USA, 2013.

46. H. Noritomi, K. Hishinuma, S. Kurihara, J. Nishigami, T. Takemoto, N. Endo, S. Kato, J. Surf. Eng. Mater. Adv. Technol. 2013, 3, 269-274. DOI:10.4236/jsemat.2013.34036www 


\section{Povzetek}

Nizkotemperaturna hidrotermalna karbonizacija (LTHTC) biomase je proces, ki temelji na reakciji biomase s subkritično vodo pri temperaturah do $250^{\circ} \mathrm{C}$. Pri tem pride do tvorbe nano- in mikro-poroznih ogljikovih struktur z reaktivno površino, ki je sestavljena iz hidroksilnih in karboksilnih skupin, ki imajo potencial za vezavo različnih spojin. Imobilizacijo encima na biooglje smo izvedli na dva načina: $\mathrm{z}$ adsorpcijo in s kovalentno vezavo $\mathrm{z}$ dodatkom mrežnega povezovalca. Proučevali smo vpliv časa imobilizacije, koncentracije encimov, vrste in koncentracije mrežnega povezovalca in vrste nosilca - biooglja (LTHTC odpadkov iz proizvodnje oljčnega olja (LTHTC OL odpadkov) ali LTHTC celuloze) na učinkovitost imobilizacije in preostale aktivnosti biokatalizatorja. Večja učinkovitost imobilizacije in preostala encimska aktivnost je bila dosežena v primeru kovalentne vezave encima na biooglje, pridobljeno z LTHTC celuloze.

Except when otherwise noted, articles in this journal are published under the terms and conditions of the Creative Commons Attribution 4.0 International License 